\title{
13. CLAY MINERALOGICAL AND INORGANIC GEOCHEMICAL STRATIGRAPHY OF BLAKE-BAHAMA BASIN SINCE THE CALLOVIAN, SITE 534, DEEP SEA DRILLING PROJECT LEG 76 ${ }^{1}$
}

\author{
Hervé Chamley, Pierre Debrabant, Anne-Marie Candillier, and Janine Foulon, Sédimentologie et Géochimie, \\ ERA 764 CNRS, Université de Lille I, 59655 Villeneuve d'Ascq Cedex, France
}

\begin{abstract}
Mineralogical and geochemical investigations carried out on Callovian to upper Cenozoic basalt and sediments of Hole 534A are the bases for paleoenvironmental interpretations. The clay mineralogy primarily reflects events that occurred on the American continent (tectonics, morphology, alteration and pedogenesis, climate), except in the basalt and at the precise basalt/sediment contact where in situ alteration and local metamorphic effects exist. The inorganic and organic geochemistry mainly reflects the influence of and increasing distance from the spreading center during the first stages of sedimentation, the terrigenous influence from the Valanginian upward, and the bottom reducing or oxidizing conditions linked to the widening and deepening of the ocean affected by global tectonics.
\end{abstract}

\section{INTRODUCTION}

Hole 534A of the Deep Sea Drilling Project, drilled during Leg 76 in the Blake-Bahama Basin (Fig. 1), successfully penetrated the oldest marine sediments known in the western North Atlantic Ocean (Sheridan et al., 1982 , and this volume). Located in the vicinity of Site 391 of Leg 44 (Benson et al., 1978), Hole 534A $\left(28^{\circ}\right.$ $20.63^{\prime} \mathrm{N}-75^{\circ} 22.89^{\prime} \mathrm{W}$; water depth, $4966 \mathrm{~m}$ ) bottomed at $1666.5 \mathrm{~m}$ below the ocean floor in a typical basaltic oceanic basement. Continuous coring was done from middle Miocene sediments downward through the middle Callovian sediments and underlying basalts. The upper Cenozoic sediments were poorly recovered in Hole 534 , but data on the sediments are available at nearby Site 391, especially for the Quaternary.

The geological formations encountered at Site 534 correspond to the classification established by Jansa et al. (1979) in the western North Atlantic, except for the oldest lithologic unit, which was sampled for the first time. The main formations are the following (Sheridan et al., 1982, and this volume; Fig. 2):

Blake Ridge Formation (0-2.8 m, Core 534-1; and 0-146.9 m, Site 391), Pleistocene: gray nannofossil ooze and silty clay.

Great Abaco Member, Blake Ridge Formation (545$696 \mathrm{~m}$, Cores 534A-1-18), middle and lower Miocene: chalks and intraclast chalks, dark green mudstones.

Bermuda Rise Formation (696-721 m approximately, Cores 534A-19-21), upper Eocene: interbedded zeolitic and siliceous, variegated mudstone, graded sandstone and porcellanite; the lower limit of the formation is somewhat imprecise.

Plantagenet Formation (721-764 m, Cores 534A-2426), lower Maestrichtian: variegated claystone.

\footnotetext{
${ }^{1}$ Sheridan, R. E., Gradstein, F. M., et al., Init. Repts. DSDP, 76: Washington (U.S Govt. Printing Office).
}

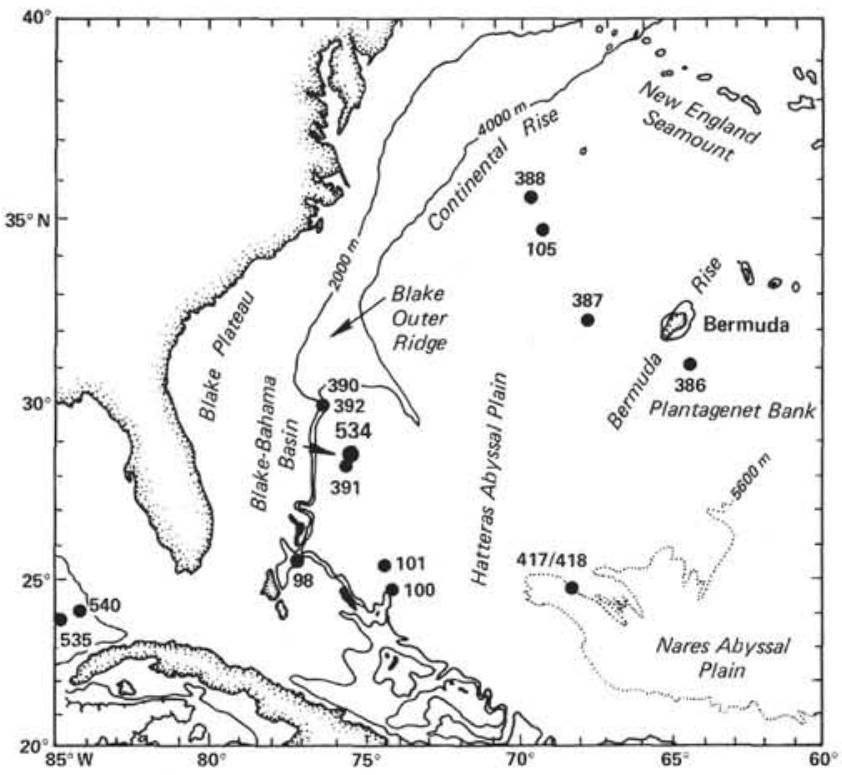

Figure 1. Location map.

Hatteras Formation (764-950 m, Cores 534A-27-46), Cenomanian-Vraconian through lower Aptian: black to green carbonaceous claystone.

Blake-Bahama Formation (950-1342 m, Cores 534A47-91), Barremian through lower Berriasian: bioturbated and laminated radiolarian-rich nannofossil limestone and chalk, grading upward into calcareous and carbonaceous claystone, resedimented shelf limestones, and quartzose siltstones.

Cat Gap Formation (1342-1496 m, Cores 534A-92111), Tithonian through Oxfordian: grayish red, calcareous claystone underlain by dark greenish gray claystone with interbedded limestone.

“'Unnamed" formation (1496-1635 m, Cores 534A112-127), lower middle Oxfordian through middle Callovian: dark-colored variegated claystone underlain by 


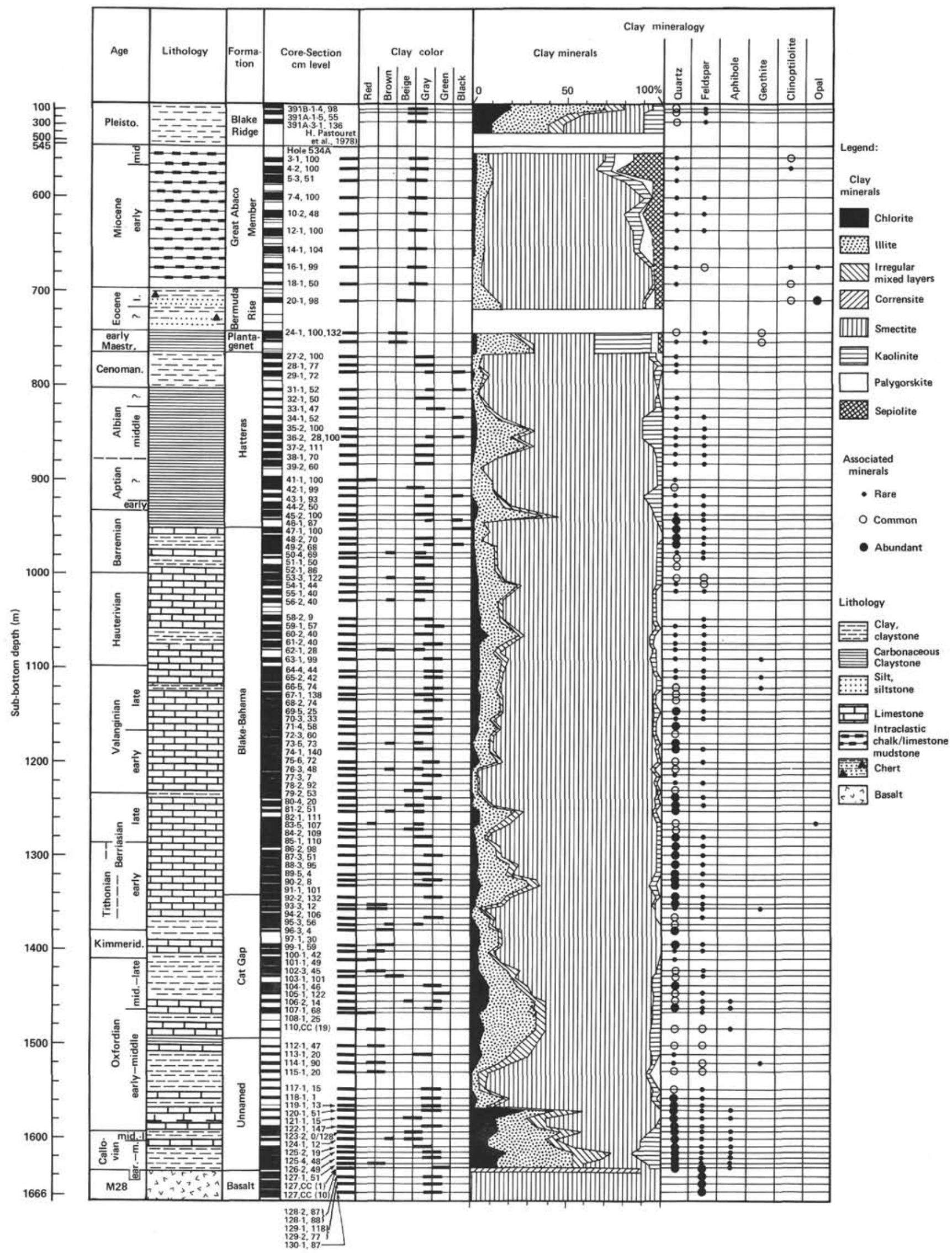

Figure 2. Hole 534A-lithology, sampling, clay mineralogy (with reference to Site 391 for the Quaternary; cf., Pastouret et al., 1978). 
olive gray pelletal limestone and radiolarian claystone, underlain by greenish black to brown nannofossil claystone terminating in reddish claystone.

Volcanic basement (1635-1666.5 m, Cores 534A-127130): dark gray aphyric to sparsely microporphyritic basalt, with thin fractures $(1-5 \mathrm{~cm})$ and interbeds $(<7 \mathrm{~cm})$ filled by green claystone and reddish brown siliceous limestone.

Among the main paleoenvironmental results and interpretations deduced from preliminary studies of Site 534 , and presented by Sheridan et al. (1982, we note the following: the Mesozoic and Cenozoic "background" sedimentation consisted of hemipelagic clayey and calcareous deposits, periodically interrupted by turbidites, debris-flows, and other resedimented materials. Most sediments were deposited during the 50 m.y. following the initiation of sedimentation at Site 534, and deposition of material inherited from the nearby carbonate platforms chiefly occurred during the Early Cretaceous and the Miocene. The oldest sediments drilledMiddle to Late Jurassic-reflect the resedimentation of margin sediments, possible alternations of oxidizing and reducing bottom conditions, and the possible existence of bottom circulation, probably related to the location of Hole 534A in a passageway between the Tethys and the Pacific Oceans.

After the Early Cretaceous deposition of mixed shelf and pelagic carbonates, the deepening of the western North Atlantic Basin and shallowing of the calcite compensation depth $(\mathrm{CCD})$ with the possible development of reducing bottom conditions led to the deposition of abundant terrigenous black shales. Oxidized conditions developed again during the Late Cretaceous with the more rapid oceanic widening, while bottom currents became active and created important hiatuses until the late Paleogene. Rapid sedimentation of terrigenous clastics started again during the Miocene and the Pliocene-Pleistocene, after the northern hemisphere changed from a nonglacial stage to a glacial one.

Our objective is to interpret Mesozoic and Cenozoic paleoenvironmental conditions in the eastern North American area and in the Blake-Bahama Basin by means of a clay mineralogical and bulk geochemical study of Site 534 materials. We examined many samples collected at regular spacing from the continuously cored section of volcanic and sedimentary rocks at Hole 534A (Fig. 2). For this study, 150 samples were submitted to X-ray diffraction, 120 to molecular and atomic absorption spectrometry, 38 to the pyrolysis of organic carbon, and 30 to transmission electron microscopy. Determinations were made of the detailed lithology and composition of sedimentary components. Interpretation of the Quaternary was based on previous data from Site 391 (Pastouret et al., 1978). Our results and interpretations based on clay mineralogy and inorganic geochemistry are discussed. Both results and interpretations are tentatively summarized in the conclusion of this chapter.

\section{ANALYTICAL PROCEDURES}

In our X-ray diffraction method, the samples were dissociated in water, then decarbonated in N/5 hydrochloric acid. Excess acid was removed by successive centrifuging. Microhomogenization affects deflocculation. Fractions smaller than $2 \mu \mathrm{m}$ were collected by decantation, using Stokes' law; then oriented pastes were made on glass slides. A Philips 1730 diffractometer (copper radiation) was used to run the X-ray diffraction scans at $2^{\circ} 2 \theta / \mathrm{mm}$. Three passages were carried out: (1) from $2.5^{\circ}$ to $28.5^{\circ} 2 \theta$ on natural samples; (2) from $2.5^{\circ}$ to $14.5^{\circ} 2 \theta$ on glycolated samples; (3) from $2.5^{\circ}$ to $14.5^{\circ} 2 \theta$ on samples heated for $2 \mathrm{hr}$. at $490^{\circ} \mathrm{C}$. Semiquantitative evaluations were based on peak heights and areas (Chamley, 1971). The height of illite and chlorite 001 peaks (diagram for glycolated sample) were taken as references. By comparison with these values, values for smectite, palygorskite, sepiolite, vermiculite, and irregular mixed-layer clays were corrected by addition of peak height, whereas values for well crystallized kaolinite were corrected by subtraction. The relative proportions of chlorite and kaolinite were determined from the ratio of peak heights $(3.54$ and $3.58 \AA$, respectively): when this ratio was 1 , the amount of chlorite was assumed to be twice that of kaolinite. Data were given in percentages, the relative error being about $\pm 5 \%$.

Electron-microscopy observations were made with a Siemens transmission microscope on less than 8- $\mu \mathrm{m}$ particles deposited on copper grids covered by a collodion film, after carbonate removal and physical deflocculation.

The geochemical procedure was as follows: the samples were dried at $105^{\circ} \mathrm{C}$, then crushed and homogenized. Then $0.2 \mathrm{~g}$ were submitted to alkaline fusion, solubilized by $\mathrm{HCl}$, and diluted to $100 \mathrm{ml} ; 0.2 \mathrm{~g}$ were then submitted to fluoronitric treatment in a bomb at $150^{\circ} \mathrm{C}$ and 50 bars for $\mathrm{SiO}_{2}$ and $\mathrm{Al}_{2} \mathrm{O}_{3}$ determination. Also, $1 \mathrm{~g}$ was submitted to fluoroperchloric treatment, then solubilized by $\mathrm{HCl}$ and diluted to $100 \mathrm{ml}$. The dilutions were used for colorimetric analysis of $\mathrm{TiO}_{2}$ and $\mathrm{P}_{2} \mathrm{O}_{5}$ and spectrophotometric analysis of other major and trace elements by atomic absorption in flame, with a type 5000 Perkin Elmer automatized spectrophotometer.

\section{CLAY MINERAL STRATIGRAPHY}

\section{Altered Basalts}

Basalt pieces, showing a weak to moderate alteration in clay, were studied in Cores 128, 129, and 130 (Samples 534A-128-1, $88 \mathrm{~cm}, 534 \mathrm{~A}-128-2,87 \mathrm{~cm}, 534 \mathrm{~A}-129-1$, $118 \mathrm{~cm}, 534 \mathrm{~A}-129-2,77 \mathrm{~cm}, 534 \mathrm{~A}-130-1,87 \mathrm{~cm}$ (Fig. 2). The extraction of clay fractions shows the presence of exclusive and highly crystallized smectite, associated with $\mathrm{Ca}-\mathrm{Na}$ feldspars. The smectite morphology includes broad boards or tufts (Plate 3, Figs. 4-6) and typically resembles $\mathrm{Fe}-\mathrm{Mg}$ minerals (Beutelspacher and Van der Marel, 1968). It is important to note that smectite represents the result of an in situ alteration of basalt, a classical phenomenon often described in DSDP materials (i.e., Rusinov et al., 1980; Scheidegger and Stakes, 1980).

\section{Basalt/Sediment Boundary}

The precise contact between the basalt and the sediments deposited immediately above has been studied in Core 127 (Figs. 2 and 3). Although altered basalt typically contains highly crystallized smectite and plagioclase feldspars, the clay fraction of the basalt/sediment contact is characterized by regular chlorite-smectite mixed layers or corrensite (Sample 534A-127,CC-[10 $\mathrm{cm}]$ ). This peculiar clay species, whose behavior under ethylenic-glycol treatment shows the dominance of chloritelike layers compared to smectitelike ones, is well crystallized, and forms up to $90 \%$ of the clay. It consists of well-shaped, highly refringent, and diversely sized clay sheets (Plate 3, Figs. 1-3). Corrensite is associated with few particles of poorly crystallized smectite, and with $\mathrm{Ca}-\mathrm{Na}$ feldspars. Nine centimeters above this contact 


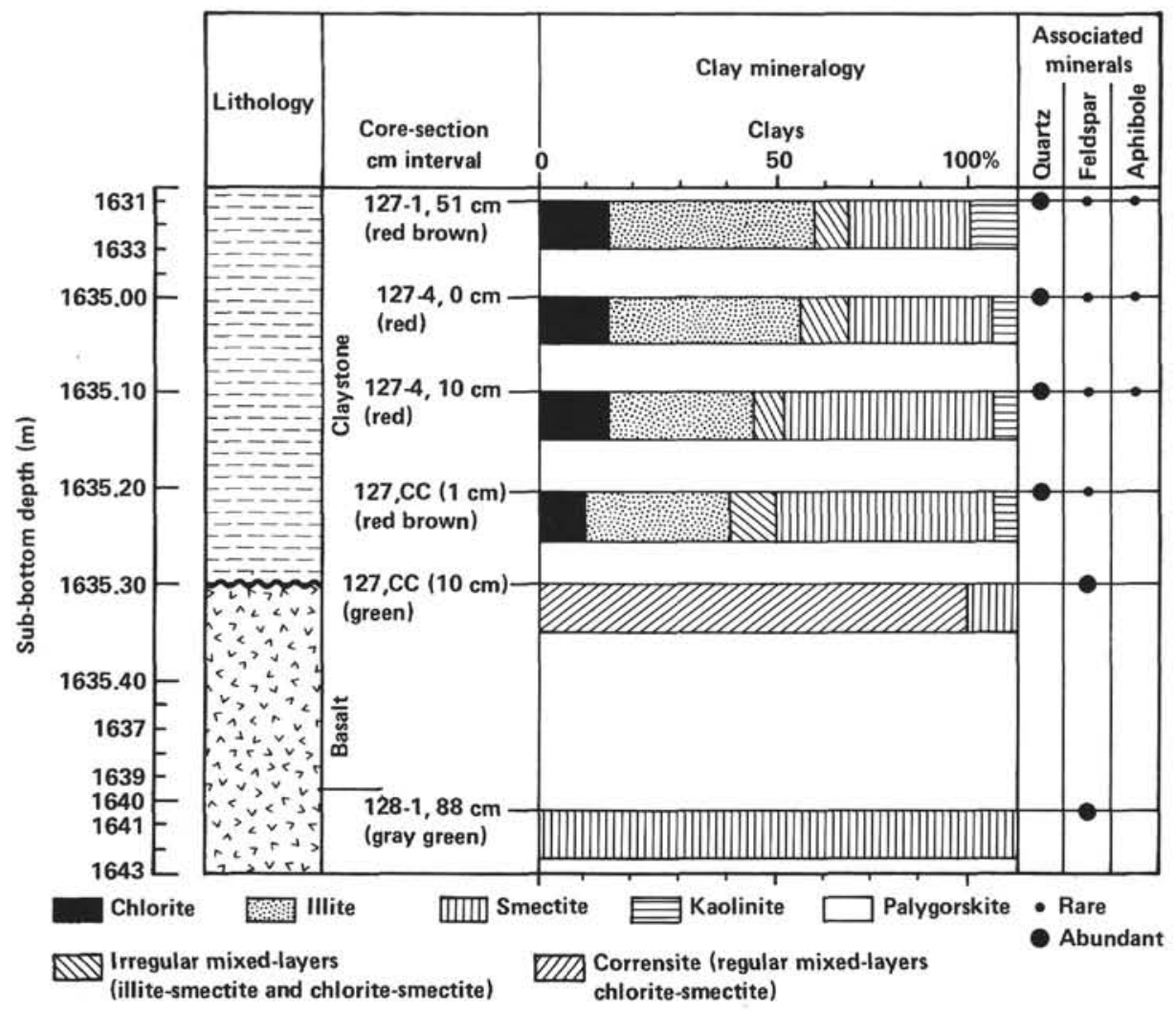

Figure 3. Clay mineralogy at the basalt/sediment boundary, Cores 128 and 127, Hole 534A.

(Sample 534A-127,CC $[1 \mathrm{~cm}]$ ) the clay mineralogy is completely modified: illite, chlorite, kaolinite, and irregular illite-chlorite and chlorite-smectite mixed layers form the dominant part of the less than $2-\mu \mathrm{m}$ fraction, and are associated with middle-crystallized smectite, abundant quartz, and little feldspar (see also Plate 2, Figs. 5, 6). Note that fewer amounts of corrensite occur above this level in the same core, in similar conditions as in the core catcher (Sample 534A-127-4, $0 \mathrm{~cm}$, basalt/ sediment contact: corrensite $25 \%$, smectite $15 \%$, illite $60 \%$ ).

This unusual clay mineralogical succession can be interpreted as follows: (1) Highly crystallized smectites are typical products of low-temperature alteration of basalts (i.e., Melson and Thompson, 1973; Juteau et al., 1980; Chamley and Bonnot-Courtois, 1981). The first clay assemblage encountered reflects the in situ alteration of volcanic rocks after their production on the seafloor. (2) Corrensite and similar regular mixed layers are known to exist on land outcrops as alteration materials formed under hydrothermal conditions, in a temperature range of 200 to $270^{\circ} \mathrm{C}$ (Kristmanndottir, 1976), and reflect a local environment typical of a contact metamorphism. The development of chlorite-smectite mixed layers and other metamorphic minerals has been described in submarine conditions by Humphris and Thompson (1978), and by Rangin et al. (in press) in the northern part of the East Pacific Rise. Accordingly, at Site 534 the sediments exactly located at the contact with volcanic units result from in situ metamorphic processes, in which the main influence consists of the basalt cooling. This indicates that the metamorphic processes above the basalt occur over very small vertical distances (less than $10 \mathrm{~cm}$ ). (3) The third clay assemblage is commonly found at other DSDP sites in the sediments deposited close to the last basalts, but not immediately at their contact (i.e., Chamley, 1979; Debrabant and Chamley, 1982). The diversification of clay minerals, the relative abundance of typical detrital minerals, the presence of middle-crystallized smectite, and various geochemical data indicate a strong supply of terrigenous materials, reworked from adjacent landmasses when the continental margins were tectonically active shortly after rifting. The importance of terrigenous input shortly after the ocean initiation is thus indicated.

\section{Unnamed, Cat Gap, and Blake-Bahama Formations Callovian to Barremian}

The three lower sedimentary units recovered at Hole 534A (1635-950 $\mathrm{m}$ below the seafloor), Callovian to Barremian in age, show similar modalities of the clay sedimentation, whose major features are discussed next.

There is no evidence of any mineralogical modifications of clay assemblages caused by the depth of burial. The similarity in the relative abundance and crystallinity of clay species identified at the top (Quaternary, Site 391 ) and at the bottom (Callovian, Hole 534A) of the sedimentary column clearly expresses this important fact. Minerals known for their peculiar vulnerability to thermodynamic effects, such as palygorskite, irregular mixed 
layers, or smectites, are as abundant in recent sediments as in oldest ones. As a result, at Site 534 there is no significant clay diagenesis with the depth of burial.

There does not exist any parallelism between the lithological successions and the mineralogical ones. The main evidence for this lack of correlation is the independence between boundaries of the major formations (unnamed, Cat Gap, Blake-Bahama) and the changes in mineralogy of the clay fraction (Fig. 2). This same lack of correlation occurs when one considers the detailed lithological and mineralogical stratigraphy. This lack points to the lack or the weakness of clay diagenesis linked to local depositional conditions at the drill site. Moreover, it is clear that qualitative and quantitative changes of clay minerals do not significantly depend on the absolute abundance of the clay fraction in sedimentary rocks. As a consequence, paleoenvironmental implications can often be deduced equally as well from sediments poor or rich in clay fraction.

The clay mineralogical background consists of abundant and well-crystallized smectites (i.e., Plate 2, Fig. 1, early Valanginian; Figs. 3 and 4, Callovian-Oxfordian). The significance of these minerals, whose abundance does not depend on sedimentation rates, lithology, petrography or nonclay mineralogy, or on geochemistry, has already been discussed in previous papers dealing with North Atlantic Mesozoic-Cenozoic sediments (i.e, Chamley, 1979, 1981; Chamley and al., 1980; Chamley and Robert, in press; Debrabant and Foulon, 1979), and only a summary is given here. Smectites in marine sediments appear to be chiefly inherited from terrigenous sources, in the same way as associated minerals such as illite, chlorite, irregular mixed layers, kaolinite, quartz, and feldspars are. The primary origin of smectites seems to be surficial continental formations, chiefly gray blackish soils developed under bad drainage conditions, in gently sloped areas that are tectonically rather stable. The large development of pedogenic smectites implies the existence of warm climates characterized by fairly dry conditions or at least marked alternations in the seasonal humidity, especially from the Latest Jurassic upward, which agrees with climatic data established by other methods (i.e., Frakes, 1979; Reyre, 1980). The occasional presence of small amounts of palygorskite (Oxfordian, Lower Cretaceous, ..., etc., Fig. 2; Plate 2, Fig. 1), whose fibers are broken and not morphologically dependent on other minerals, indicates reworking. This palygorskite supports the interpretation of depressed continental coastal areas, favoring the confined and evaporating conditions necessary for smectite crystallizations (Millot, 1964).

During several periods the smectitic background was altered by an important supply of illite, accompanied by chlorite, irregular mixed layers, quartz and feldspars, sometimes kaolinite, palygorskite, goethite, and amphiboles. These "illite events" occurred with various intensities, and illite particles generally show good crystallinities and morphologies (Plate 2, Figs. 2, 5, and 6). The main "illite events" occurred during the Callovian-early Oxfordian, just above the oceanic basalts (Cores 127120), during the middle-late Oxfordian (Cores 114
112), during the Tithonian-early Berriasian (Cores 9893), and during the late Berriasian (Cores 83, 82). These events, which recent studies show to be synchronous at various DSDP western north Atlantic and Gulf of Mexico sites (Legs 11, 44, 76, 77; Chamley et al., 1980; Debrabant and Chamley, 1982; and unpublished research), seem to correspond to the recurrence of erosion on the North American landmass, leading to heterogeneous supply to the ocean basin of products reworked from soils, weathered zones, and underlying bedrock. The erosional-event renewals themselves are attributed to a morphological rejuvenation of the continental margins, possibly caused by aperiodic tectonic modifications, especially in connection with the major seafloor spreading stages. Note that for all the time intervals considered, the "illite events" correspond to rather high sedimentation rates and abundant resedimentation structures (Sheridan et al., 1982), which agree with the importance of strong continental erosion. Note also that the decrease of smectite in the Cat Gap and unnamed formations, already identified during Leg 76 aboard the Glomar Challenger (see Site 534 report), corresponds to increases of the illite group, attributed here to changes in the terrigenous supply rather than to in situ geochemical changes.

Except for the lowermost part of the sedimentary column at Site 534, kaolinite is rare or even absent from the Callovian to the Barremian (Plate 2). The relative abundance of this mineral in the first sediments deposited probably results from the strong influence of continental tectonic activity and the inferred detrital supply in the earliest stages of ocean formation as well as from climatic conditions that were more humid than later on (i.e., Reyre, 1980). The rareness of kaolinite the rest of the time, during periods known for the common production of kaolinite in well-drained continental areas (i.e, Decommer and Chamley, 1981), is attributed to a combination of factors preventing its supply to the open marine basin from continental areas (Chamley et al., 1980). These factors are the immature morphology of river drainage systems generated by the just recent formation of the new ocean basin; the large extent of upstream sources of the mineral, favoring differential settling processes; the dominance of flat morphology favorable to smectite pedogenic development; the importance of carbonate platforms acting as submarine barriers to the rapidly sedimented kaolinite, and so on. Note that in a general way kaolinite increases correspond to illite ones, which points to their dependence on similar causes of reworking (see the earlier discussion).

\section{Hatteras and Plantagenet Formations, Middle to Late Cretaceous}

The clay sedimentation from the Aptian to the Maestrichtian, marked by important hiatuses, resembles that of previous times, and shows the occurrence of strong "illite events" in a "smectite background." The three main "illite events" occurred during the late Barremian to the early Aptian (Cores 46, 45), during the Albian (Cores 38-34), and during the Maestrichtian (Cores 25, 24). Their origin probably lies in temporary tectonic re- 
juvenations occurring on a rather stable continent, with a warm and episodically humid climate, as during the earlier Mesozoic periods. Note that we could not find any relationships in the Hatteras Formation among quartz, smectite, mixed layers, and kaolinite, or between "marine" clay in the lower part and "land" clay in the upper part, relationships suggested by shipboard preliminary analyses (Site 534 report, this volume). However, some features of the clay mineralogy characterize this geological interval; these features are discussed next.

Kaolinite is commonly represented and is relatively abundant (Fig. 2; Plate 1, Figs. 3-6), which suggests either a morphological maturation of river basin systems and/or the occurrence of stronger tectonic rejuvenations, permitting the distant supply of minerals eroded from upstream soils. The second hypothesis, favoring the highly detrital character of the sedimentation, agrees with the abundance of turbidites and continental organic matter, especially in the dark black shales of the Hatteras Formation (Sheridan et al., 1982). Kaolinite is peculiarly abundant during the Late Cretaceous "illite event" (Plantagenet Formation, variegated claystone, Maestrichtian; Plate 1, Figs. 3-5) and is associated with goethite and subamorphous iron oxides. This event is known to have recurred in the whole Atlantic Ocean between the Campanian and the early Paleocene (Chamley and Robert, 1979). It followed the major spreading stage responsible for the definitive communication between the North and South Atlantic and the inferred development of deep-water circulations (Berggren and Hollister, 1977). It also corresponded to the Late Cretaceous opening on the Labrador Sea.

In general and especially during the "illite events," chlorite, quartz, and feldspars are less abundant than in the underlying sedimentary formations, nor do they follow the illite quantitative fluctuations in the same proportion (Fig. 2). On electromicrographs, the mean sizes of primary clay minerals (illite, chlorite) are often smaller than usual. Both facts probably are the result of longdistance transport of terrigenous materials, which does not favor large-sized minerals such as chlorite and especially quartz and feldspars. Such an explanation agrees with the distant sources of kaolinite. Moreover it is not at variance with the highly detrital character of the sedimentation, most of the turbidite facies being of a distal type.

Palygorskite, which disappeared in the upper part of the Blake-Bahama Formation (uppermost Hauterivian), is present again in the upper part of the Hatteras Formation (upper Albian, Vraconian). The fibrous clay occurs first in small amounts. Its abundance increases slightly in the Plantagenet Formation, in which it is accompanied by a small quantity of sepiolite (Plate 1, Figs. 3-5). The typical terrigenous character of the variegated Maestrichtian claystone, combined with the morphological independence of various kinds of clay minerals, confirms the detrital origin of fibrous species, certainly reworked from Upper Cretaceous perimarine basins where they formed under confined alkaline conditions (see Millot, 1964; Chamley, 1979; Giblin, 1979).

\section{Bermuda Rise and Blake Ridge Formations, Cenozoic}

The only levels of the Bermuda Rise Formation recovered are from the upper Eocene and contain abundant smectites, probably of a pedogenic origin, as previously. Soils formed under temperate-warm to subtropical conditions, in an episodically humid climate, have been recently described in the Eocene of the United States, which strengthens the comparison with upper Cenozoic blackish soils of subarid areas (Millot, 1964; Paquet, 1969). Smectites are associated with clinoptilolite and opal CT typically formed during early diagenetic processes. Palygorskite and sepiolite also occur, but in smaller amounts than in lower Eocene sediments, which have been recovered at numerous other DSDP drill sites (Chamley, 1979, 1981).

Overlying the Eocene series, the lower to middle Miocene chalk and mud of the Great Abaco Member (Blake Ridge Formation) are characterized by the presence of fibrous clays, whose amounts increase irregularly upward (Plate 1, Figs. 1 and 2); clinoptilolite is sometimes still present. The fibers show various lengths, morphological associations, and preservational states. They are contemporaneous with the large development of fibrous clays described in the southeastern United States (Weaver and Beck, 1977). Occurring in intraclast chalks, in which shelf- and slope-reworked materials and slump structures are abundant, the fibrous clays were deposited at a rapid sedimentation rate and in open marine conditions (Sheridan et al., 1982) and are considered as mainly detrital materials derived from Miocene perimarine basins.

The Pleistocene sediments of the Blake Ridge Formation (Site 391, Holes 391A and B) show a strong increase of chlorite, illite, and irregular mixed layers (illite-vermiculite, illite-smectite, and chlorite-smectite), whereas smectite abundance and crystallinity decrease. This mineralogical change typically reflects the late Cenozoic cooling of the northern hemisphere, favoring the supply of minerals derived from continental rocks (decrease of hydrolysis processes) and high-latitude oceanic currents.

\section{INORGANIC GEOCHEMICAL STRATIGRAPHY}

\section{Altered Basalts}

The five basalt pieces studied in Cores 129 and 127 are characterized by high values of $\mathrm{Fe}, \mathrm{Mg}, \mathrm{Mn}$, and $\mathrm{Cu}$; average $\mathrm{Al}_{2} \mathrm{O}_{3}$ contents of $17 \%$; low values of $\mathrm{SiO}_{2}$ / $\mathrm{Al}_{2} \mathrm{O}_{3}$ ratios $(<3)$ and $\mathrm{Ni} / \mathrm{Cu}$ ratios $(<1)$; and high $\mathrm{Na}_{2} \mathrm{O} / \mathrm{K}_{2} \mathrm{O}$ ratios ( $\gg 1$ ) (Fig. 4, Table 1). The basalts of Core 129 show higher values of $\mathrm{Si}, \mathrm{Ca}, \mathrm{Na}$, and $\mathrm{Sr}$ than do those of Core 127, which are richer in Fe and $\mathrm{Mg}$. These differences seem to have a primary origin rather than to be due to secondary alterations, because each group of volcanic flows is marked by a homogeneous chemical composition.

\section{Basalt/Sediment Boundary}

The contact between volcanic and under- and overlying sedimentary rocks is strongly marked by chemical 
parameters in Core 129, Section 1,128 to $140 \mathrm{~cm}$, where two basalt flows are separated by chilly glass and siliceous limestones. The diversified composition of basalts gives way to high contents of free silica and $\mathrm{CaCO}_{3}$, with noticeable amounts of iron and manganese oxides $(\mathrm{Mn}=6400 \mathrm{ppm})$. These characteristics correspond to high values of parameter

$$
\mathrm{Mn}^{*}=\log \left(\frac{\mathrm{Mn} \text { sample }}{\text { Mn shales }} / \frac{\mathrm{Fe} \text { sample }}{\mathrm{Fe} \text { shales }}\right) \text {, }
$$

and low values of parameter $D=\mathrm{Al} /(\mathrm{Al}+\mathrm{Fe}+\mathrm{Mn})$ (see Debrabant and Foulon, 1979, and Fig. 4). The lack of $\mathrm{Ti}$ (Table 1) indicates that the siliceous limestone formation does not depend significantly on volcanic or terrigenous influence, but rather proceeds from an in situ precipitation. In Core 124 , Section $4,0 \mathrm{~cm}$, the transition from basalt to overlying argillaceous sediments corresponds to a low increase in $\mathrm{Mg}, \mathrm{Na}$, and $\mathrm{Fe}$ contents. In Sample 127, CC $(0 \mathrm{~cm})$, the hydrothermal development of corrensite is marked by a slight decrease of $\mathrm{Ni}, \mathrm{Cr}$, $\mathrm{Cu}$, and $\mathrm{V}$.

\section{Unnamed Formation}

The irregular alternation of dark claystones and of limestones deposited during the Callovian to middle Oxfordian determines a geochemical heterogeneity in $\mathrm{Mn}$ contents, because $\mathrm{Mn}$ is preferentially precipitated in oxidized calcareous environments and rather dissolved in reduced clayey environments $\left(\mathrm{C}_{\text {org }}>2 \%\right.$ in dark claystones). The intercalations of brown to reddish claystones in limestones correspond to the reworking of fine materials, previously deposited in more oxidized and less deep conditions, favoring the fixation of Mn.

When considering a given lithology such as the limestones, the unnamed formation (Cores 127-112) is characterized by high amounts of iron and manganese $(D$, low; $\mathrm{Mn}^{*}$, middle to high). These data point to a proximal volcanic influence, suggesting the vicinity of the Late Jurassic spreading center (Debrabant and Foulon, 1979); the strong volcanic and hydrothermal influence also is indicated by the fairly high amounts of $\mathrm{Zn}$ and $\mathrm{Cu}(\mathrm{Ni} / \mathrm{Cu}<1$ until Core 113$)$.

A geochemical break occurs close to the beginning of the Oxfordian stage (Core 120), marked by a development of $\mathrm{Ca}$. The underlying series are characterized by high contents of free silica and metalliferous traces, corresponding to the abundance of illite, chlorite, quartz, and other "primary" minerals (see the earlier discussion). Note that most of the limestones of the unnamed formation strongly differ from siliceous limestones interbedded in basalt flows (i.e., Core 129). Only Sample $534 \mathrm{~A}-120-1,51 \mathrm{~cm}$ shows increased amounts of $\mathrm{SiO}_{2}$ and $\mathrm{Mn}$, and correlative decreased amounts of $\mathrm{TiO}_{2}$, $\mathrm{Fe}, \mathrm{Ni}, \mathrm{Ca}$, and $\mathrm{V}$ linked to the clay fraction; this sample is also marked by high values of $\mathrm{Sr}(3.72 \%)$, probably due to the diagenetic precipitation of strontianite.

\section{Cat Gap Formation}

The geochemical heterogeneity of Oxfordian to $\mathrm{Ti}$ thonian sediments (Cores 110-93) resembles the one identified in the unnamed formation, and results from the selective precipitation of $\mathrm{Mn}$ in allochthonous limestones, and the selective dissolution of $\mathrm{Mn}$ in reduced claystones deposited in situ. The high amounts of Fe recovered in the claystones (low values of parameter $D$ ), and the high concentrations of $\mathrm{Mn}$ in limestones (high values of Mn*), together with abundant $\mathrm{Zn}(3000 \mathrm{ppm}$ in Core 105) and Cu contents, point to the vicinity of the spreading center, allowing proximal influences of volcanism. The values of $\mathrm{Zn}$ suddenly decrease at the Kimmeridgian/Tithonian boundary, and the $\mathrm{Ni} / \mathrm{Cu}$ ratio becomes higher than 1, suggesting a removal of the site from the spreading center.

Some direct correspondences exist between the occurrences of allochthonous carbonates marked by variable contents of $\mathrm{Sr}$ and the relative abundance of the "illite group." The latter being typically terrigenous and therefore of a North American origin, it is likely that the calcareous turbidites proceeded from reworking processes on the continental margin rather than on the mid-oceanic ridge.

\section{Blake-Bahama Formation}

The Tithonian to Valanginian part of this formation spans Cores 92 to 52 . Three main geochemical changes occur along the sedimentary column, grading upward from more calcareous to more argillaceous materials: (1) the Fe content strongly decreases close to the Tithonian/Berriasian boundary, whereas $\mathrm{Mn}^{*}$ values remain relatively high and follow the carbonate fluctuations. This change reflects the transition from a proximal to a distal influence of the mid-oceanic ridge (Debrabant and Foulon, 1979; Debrabant and Chamley, 1982). (2) Near the transition from Berriasian to Valanginian, Mn* values decrease, pointing to the disappearance of the distal influence of the spreading center. The values of parameter $D$ are close to 0.60 from the Jurassic/Cretaceous boundary, which characterizes the terrigenous influence on deep Atlantic sedimentation, typical of most Mesozoic and Cenozoic environments. The progressive development of claystones, marked by abundant smectites, is clearly expressed, from the Valanginian upward, by the progressive increase of $\mathrm{Na}_{2} \mathrm{O} / \mathrm{K}_{2} \mathrm{O}$ and $\mathrm{Al}_{2} \mathrm{O}_{3} / \mathrm{K}_{2} \mathrm{O}$ ratios. Minor relationships exist between the maxima of these ratios and the higher contents of smectites. (3) The passage of $\mathrm{Mn}^{*}$ from positive to negative values corresponds to the Neocomian development of smectites, attributed to a tectonic relaxation and the pedogenic clay formation on adjacent landmasses. This change is contemporary with the decrease of calcareous turbidites and detrital quartz. The upper part of the sedimentary column considered (upper Valanginian-Hauterivian, Cores 70-52) is marked by the higher geochemical stability of the whole series and corresponds to fairly high contents of organic matter, confined environments, lack of volcanic influence, and regular terrigenous supply. Note that the organic matter probably determines the chemical complexion of $\mathrm{Zn}$ (abundant from Core 67 upward), and that the dolomite occurrence at the middle to upper Valanginian transition cor- 


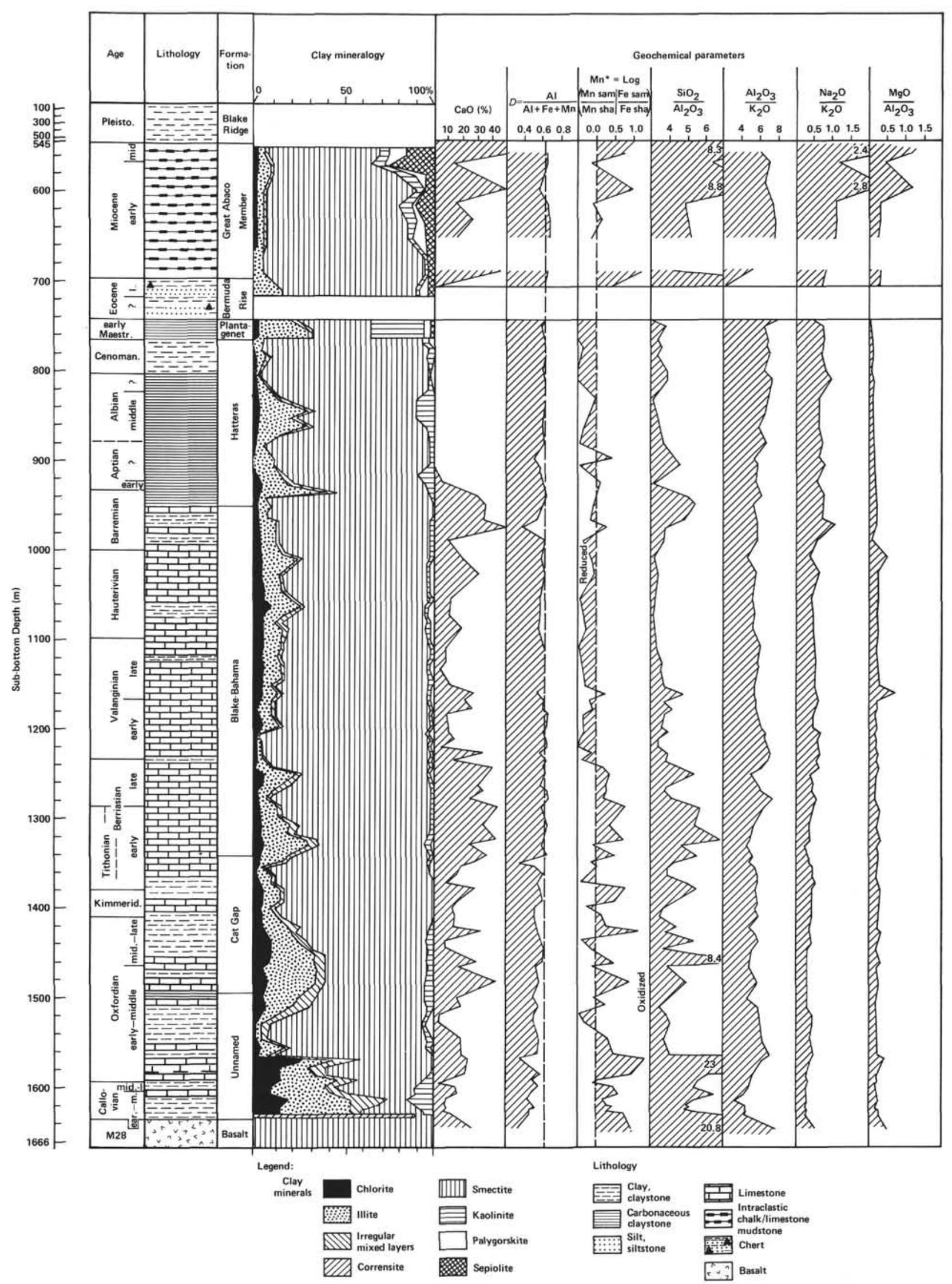

Figure 4. Hole 534A, inorganic geochemistry, compared to clay minerals data. (See the position of samples and other detailed data on Fig. 2.) 
Table 1. Inorganic geochemical data, Hole 534A.

\begin{tabular}{|c|c|c|c|c|c|c|}
\hline $\begin{array}{l}\text { Sample } \\
\text { (core-section, } \\
\mathrm{cm} \text { from top of } \\
\text { section) }\end{array}$ & $\begin{array}{l}\mathrm{SiO}_{2} \\
(\%)\end{array}$ & $\underset{(\%, 0)}{\mathrm{Al}_{2} \mathrm{O}_{3}}$ & $\begin{array}{l}\mathrm{CaO} \\
(\%)\end{array}$ & $\begin{array}{c}\mathrm{MgO} \\
(\%)\end{array}$ & $\begin{array}{c}\mathrm{Na}_{2} \mathrm{O} \\
(\%)\end{array}$ & $\begin{array}{l}\mathrm{K}_{2} \mathrm{O} \\
\left(\%_{0}\right)\end{array}$ \\
\hline $3-1,100$ & 11.60 & 1.32 & 47.01 & 1.51 & 0.51 & 0.21 \\
\hline $4-2,100$ & 50,33 & 8.03 & 14.94 & 3.54 & 1.33 & 1.11 \\
\hline $\begin{array}{l}7-4,100 \\
0.2,4\end{array}$ & $\begin{array}{r}6.67 \\
47.33\end{array}$ & 0.76 & $\begin{array}{l}52.96 \\
15.39\end{array}$ & $\begin{array}{l}0.91 \\
3.30\end{array}$ & 0.33 & 0.12 \\
\hline $\begin{array}{l}10-2,48 \\
12-1,100\end{array}$ & $\begin{array}{l}47.33 \\
37.50\end{array}$ & $\begin{array}{l}9.64 \\
7.37\end{array}$ & $\begin{array}{l}15.39 \\
26.93\end{array}$ & $\begin{array}{l}3.39 \\
3.13\end{array}$ & 1.31 & 1.28 \\
\hline $14-1,104$ & 50.33 & 9.64 & $\begin{array}{l}26.93 \\
15.29\end{array}$ & $\begin{array}{l}2.13 \\
2.09\end{array}$ & 1.05 & 0.93 \\
\hline $18-1,50$ & 13.00 & 3.02 & $\begin{array}{l}45.29 \\
45.58\end{array}$ & $\begin{array}{l}2.09 \\
1.01\end{array}$ & $\begin{array}{l}1.37 \\
0.48\end{array}$ & 0.58 \\
\hline $20-1,99$ & 82.60 & 6.21 & 0.65 & 0.88 & 1.20 & 1.69 \\
\hline $24-1,100$ & 70.17 & 14.08 & 0.38 & 1.29 & 1.14 & 2.61 \\
\hline $24-1,132$ & 58.33 & 21.26 & 0.35 & 1.51 & 1.21 & 2.61 \\
\hline $25-1,101$ & 64.17 & 16.25 & 0.52 & 1.46 & 1.86 & 2.50 \\
\hline $27-2,100$ & 60.67 & 17.29 & 0.45 & 2.57 & 1.99 & 2.46 \\
\hline $28-1,77$ & 62.50 & 16.91 & 0.56 & 2.54 & 1.88 & 2.46 \\
\hline $29-1,72$ & 59.33 & 17.19 & 0.49 & 2.50 & 1.76 & 2.43 \\
\hline $31-1,52$ & 61.67 & 15.40 & 0.45 & 1.10 & 2.00 & 2.37 \\
\hline $32-1,50$ & 64.50 & 16.15 & 0.49 & 2.32 & 2.16 & 2.16 \\
\hline $34-1,52$ & 57.50 & 17.85 & 0.98 & 2.33 & 1.66 & 2.51 \\
\hline $36-2,28$ & 62.17 & 17.67 & 0.63 & 2.13 & 1.76 & 2.66 \\
\hline $37-1,111$ & 61.33 & 17.29 & 0.45 & 2.65 & 1.87 & 2.94 \\
\hline $39-2,60$ & 63.33 & 16.53 & 0.59 & 2.74 & 1.86 & 2.44 \\
\hline $41-1,100$ & $\begin{array}{l}63.17 \\
66.33\end{array}$ & $\begin{array}{l}14.36 \\
13.41\end{array}$ & 0.84 & 2.62 & 1.74 & 2.66 \\
\hline $\begin{array}{l}42-1,999 \\
44-2,50\end{array}$ & $\begin{array}{l}66.33 \\
50.33\end{array}$ & $\begin{array}{l}13.41 \\
15.87\end{array}$ & $\begin{array}{l}0.45 \\
6.58\end{array}$ & $\begin{array}{l}2.41 \\
2.63\end{array}$ & $\begin{array}{l}1.79 \\
1.62\end{array}$ & $\begin{array}{l}2.28 \\
2.82\end{array}$ \\
\hline $46-1,87$ & 32.00 & 6.24 & $\begin{array}{l}0.38 \\
30.85\end{array}$ & $\begin{array}{l}2.03 \\
1.32\end{array}$ & $\begin{array}{l}1.62 \\
0.76\end{array}$ & $\begin{array}{l}2.82 \\
0.98\end{array}$ \\
\hline $47-1,100$ & 23.00 & $\begin{array}{l}4.24 \\
4.16\end{array}$ & 36.48 & $\begin{array}{l}1.32 \\
1.00\end{array}$ & 0.57 & 0.77 \\
\hline $49-2,68$ & 23.33 & 5.01 & 35.75 & 1.16 & 0.64 & 0.86 \\
\hline $50-4,69$ & 6.67 & 1.70 & 50.48 & 0.80 & 0.32 & 0.29 \\
\hline $52-1,86$ & 50.00 & 13.04 & 10.81 & 2.53 & 1.37 & 2.26 \\
\hline $54-1,44$ & 33.67 & 10.30 & 20.11 & 5.51 & 0.89 & 2.18 \\
\hline $56-2,40$ & 26.67 & 7.56 & 31.87 & 2.11 & 0.90 & 1.33 \\
\hline $59-1,57$ & 44.67 & 13.41 & 12.59 & 3.84 & 1.11 & 2.52 \\
\hline $61-2,40$ & 46.50 & 14.55 & 10.67 & 3.52 & 1.27 & 2.61 \\
\hline $63-1,99$ & 36.67 & 11.05 & 20.18 & 3.07 & 1.04 & 2.09 \\
\hline $65-2,42$ & 49.83 & 14.74 & 9.06 & 3.23 & 1.34 & 2.38 \\
\hline $67-1,138$ & 49.50 & 13.23 & 9.48 & 3.01 & 1.25 & 2.24 \\
\hline $68-2,74$ & 53.90 & 14.95 & 5.32 & 3.55 & 1.40 & 2.49 \\
\hline $70-3,33$ & 45.40 & 12.04 & 12.69 & 3.70 & 1.13 & 2.17 \\
\hline $71-4,58$ & $\begin{array}{l}27.60 \\
35.60\end{array}$ & 5.72 & 27.80 & 4.20 & 0.59 & 1.04 \\
\hline $\begin{array}{l}72-3,60 \\
73-5\end{array}$ & $\begin{array}{l}35.60 \\
26.20\end{array}$ & $\begin{array}{l}9.42 \\
6.15\end{array}$ & $\begin{aligned} 21.86 \\
\end{aligned}$ & 2.29 & 1.04 & 1.63 \\
\hline $\begin{array}{l}73-5-7,73 \\
74-1,140\end{array}$ & $\begin{array}{l}26.20 \\
48.10\end{array}$ & $\begin{array}{r}6.15 \\
12.70\end{array}$ & $\begin{array}{l}30.19 \\
071\end{array}$ & $\begin{array}{l}1.56 \\
250\end{array}$ & 0.61 & 1.08 \\
\hline $75-6,72$ & 50.60 & $\begin{array}{l}12.70 \\
13.78\end{array}$ & $\begin{array}{l}9.11 \\
10.37\end{array}$ & $\begin{array}{l}2.52 \\
3.62\end{array}$ & $\begin{array}{l}1.09 \\
1.13\end{array}$ & $\begin{array}{l}2.16 \\
2.20\end{array}$ \\
\hline $76-3,48$ & 50.20 & 12.39 & 10.49 & 2.61 & 1.29 & 1.84 \\
\hline $77-3,7$ & 42.80 & 12.36 & 14.69 & 3.04 & 1.15 & 1.86 \\
\hline $78-2,92$ & 55.90 & 16.01 & 5.53 & 3.44 & 1.45 & 2.27 \\
\hline $79-2,53$ & 23.30 & 5.85 & 34.24 & 1.62 & 0.55 & 0.81 \\
\hline $80-4,20$ & 46.90 & 12.11 & 14.69 & 2.75 & 1.03 & 1.72 \\
\hline $81-3,51$ & 13.40 & 2.79 & 41.67 & 0.80 & 0.28 & 0.44 \\
\hline $82-1,111$ & 21.40 & 3.93 & 38.33 & 1.00 & 0.32 & 0.78 \\
\hline $83-5,107$ & 28.80 & 7.27 & 30.64 & 1.61 & 0.61 & 1.22 \\
\hline $84-2,109$ & 23.80 & 6.26 & 34.42 & 1.35 & 0.47 & 1.02 \\
\hline $85-1,110$ & 35.20 & 8.37 & 25.95 & 1.71 & 0.66 & 1.13 \\
\hline $86-2,98$ & 13.30 & 2.30 & 44.94 & 0.74 & 0.18 & 0.36 \\
\hline $88-3,95$ & 26.00 & 4.78 & 34.47 & 1.21 & 0.33 & 0.88 \\
\hline $90-2,8$ & $\begin{array}{l}15.60 \\
36.50\end{array}$ & 2.28 & 43.63 & 0.85 & 0.19 & 0.45 \\
\hline $\begin{array}{l}91-1,101 \\
92-2,132\end{array}$ & $\begin{array}{l}36.50 \\
22.70\end{array}$ & $\begin{array}{l}7.84 \\
4.03\end{array}$ & $\begin{array}{l}26.06 \\
37.63\end{array}$ & 2.01 & 0.45 & 1.71 \\
\hline $\begin{array}{l}93-3,12 \\
92-21\end{array}$ & 30.00 & $\begin{array}{l}6.03 \\
6.90\end{array}$ & $\begin{array}{l}37.63 \\
28.33\end{array}$ & $\begin{array}{l}1.12 \\
1.72\end{array}$ & $\begin{array}{l}0.27 \\
0.54\end{array}$ & 0.75 \\
\hline $94-2,106$ & 41.75 & 10.39 & 18.98 & $\begin{array}{l}1.72 \\
2.59\end{array}$ & $\begin{array}{l}0.34 \\
0.87\end{array}$ & $\begin{array}{l}1.43 \\
1.87\end{array}$ \\
\hline $95-3,56$ & 43.90 & 11.12 & 16.73 & 2.45 & 0.92 & 1.92 \\
\hline $96-3,4$ & 52.50 & 12.19 & 9.33 & 3.10 & 1.16 & 2.06 \\
\hline $97-1,30$ & 32.80 & 5.90 & 29.22 & 1.89 & 0.48 & 1.06 \\
\hline $99-1,59$ & 41.70 & 9.90 & 16.69 & 2.64 & 0.79 & 1.70 \\
\hline $100-1,42$ & 45.00 & 12.09 & 13.81 & 3.31 & 0.98 & 2.19 \\
\hline $101-1,49$ & 42.00 & 11.94 & 15.87 & 2.83 & 0.94 & 2.04 \\
\hline 3,45 & 4 & 10.49 & 15.06 & 2.43 & 0.86 & 2.16 \\
\hline $103-1,101$ & 23.70 & 6.20 & 33.54 & 2.16 & 0.44 & 1.13 \\
\hline$-1,46$ & & 10.96 & 8.28 & 2.82 & 0.81 & 1.84 \\
\hline $105-1,122$ & 51.70 & 13.93 & 9.78 & 2.96 & 0.85 & 2.69 \\
\hline $107-1,68$ & 34.50 & 4.09 & 30.86 & 1.30 & 0.27 & 0.83 \\
\hline $108-1,25$ & 44.20 & 11.23 & 17.65 & 2.53 & 0.74 & 2.32 \\
\hline $110, \mathrm{cc}, 19$ & $\begin{array}{l}16.70 \\
44.00\end{array}$ & 3.33 & $\begin{array}{l}43.40 \\
-49\end{array}$ & 0.94 & 0.19 & 0.58 \\
\hline $\begin{array}{l}112-1,47 \\
113,1,20\end{array}$ & $\begin{array}{l}44.00 \\
39.80\end{array}$ & $\begin{array}{l}11.05 \\
11.31\end{array}$ & 16.87 & 2.37 & 0.68 & 2.38 \\
\hline $\begin{array}{l}1,20 \\
1,90\end{array}$ & $\begin{array}{l}39.80 \\
55.33\end{array}$ & $\begin{array}{l}11.31 \\
14.17\end{array}$ & $\begin{array}{r}20.11 \\
5.07\end{array}$ & $\begin{array}{l}2.12 \\
2.74\end{array}$ & $\begin{array}{l}0.60 \\
1.05\end{array}$ & $\begin{array}{l}1.95 \\
2.37\end{array}$ \\
\hline $115-1,26$ & & 13.76 & 5.44 & 2.59 & 1.03 & $\begin{array}{l}2.37 \\
2.27\end{array}$ \\
\hline $117-1$, is & & 10.46 & 19.92 & 2.13 & & 1.67 \\
\hline $119 \cdot 1,113$ & & 9.64 & 19.92 & 2.27 & 0 & 1.36 \\
\hline 1,51 & & $\begin{array}{l}1.52 \\
1.52\end{array}$ & $\begin{array}{l}24.54 \\
24.92\end{array}$ & & & 0.21 \\
\hline 1,147 & & 6.04 & 22.80 & & & i. \\
\hline 2,0 & & 9.73 & 9. & & & \\
\hline 2, 108 & & 10.82 & 5. & 2. & & \\
\hline 12 & & 9.13 & 15 & i. & & 0 \\
\hline $125-2$, & & 7. & 17. & 1.64 & & 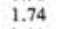 \\
\hline $125-4$, & & 9.73 & 9.8 & & & \\
\hline $126-3$ & & 10.52 & 9.18 & 2. & & \\
\hline $127-1,51$ & & 10.46 & 9.02 & 2. & & \\
\hline $127-4,0$ & & 10.96 & 9.76 & 3.19 & 0. & \\
\hline $127-4,0 \beta$ & & $\begin{array}{l}17.00 \\
10.50\end{array}$ & $\begin{array}{l}2.73 \\
7.57\end{array}$ & 11.38 & 1.73 & 0.46 \\
\hline $127-4,10$ & & 10.50 & $\begin{array}{r}7.57 \\
1.45\end{array}$ & 3.13 & 0. & 2.31 \\
\hline $\begin{array}{l}127, \mathrm{CCC}(1) \\
127 . \mathrm{CC}\end{array}$ & & $\begin{array}{r}8.26 \\
16.75\end{array}$ & $\begin{array}{c}13.45 \\
5.97\end{array}$ & $\begin{array}{r}2.60 \\
\end{array}$ & 0. & 1.91 \\
\hline $\begin{array}{l}127, C C(10), 3 \\
129-1,1183\end{array}$ & & & $\begin{array}{l}5.97 \\
9.02\end{array}$ & 11.08 & i. & 0.18 \\
\hline 1.1 & & 2. & & $\begin{array}{l}8.53 \\
2.79\end{array}$ & & \\
\hline Sed. $129-1$, 1 & & 0 & 32.38 & 1.42 & & \\
\hline $129-1,1408$ & 47.20 & 16.77 & 6.66 & 9.15 & 2.10 & 0.89 \\
\hline $129-2,77 \beta$ & 47.70 & 16.76 & 9.86 & 8.40 & 2.00 & 0.26 \\
\hline
\end{tabular}

Note: $\mathrm{C}_{\mathrm{org}}=$ organic carbon analyzed by pyrolysis; $\beta=$ basalt; and sed. $=$ sediments in basalt. 
responds to local geochemical changes (i.e., $\mathrm{MgO} /$ $\mathrm{Al}_{2} \mathrm{O}_{3}$ ).

The Barremian part of the formation ranges from Cores 50 to 46 . Lithologically considered as a transition facies between the Blake-Bahama and Hatteras formations, the Barremian claystones and limestones-chalk alternations are geochemically well defined: carbonate amounts are high (up to $90 \% \mathrm{CaCO}_{3}$ ), as well as those of organic matter $\left(3.7 \% \mathrm{C}_{\text {org }}\right.$ in Sample 534A-47-1, 100 $\mathrm{cm}$ ). The upper Barremian (Cores 47 and 46 ) indicates, together with the strong increase of the "illite group," the development of free silica and locally of phosphatizations, which supports the hypothesis of a tectonic rejuvenation.

\section{Hatteras and Plantagenet Formations}

The middle to Upper Cretaceous carbonaceous claystones of the Hatteras Formation are characterized by the disappearance of $\mathrm{CaCO}_{3}$ (cf., $\mathrm{CaO}$, Fig. 4), due to the strong shallowing of the carbonate compensation depth. The environment remains reduced $\left(\mathrm{Mn}^{*}<\mathrm{O}\right)$ and marked by variable amounts of organic matter (peaks in Cores 39,34, and 29), and locally high values of $\mathrm{Zn}$ and $\mathrm{Cu}$ (Table 1). Note the rareness of organic matter in some levels of the base of the formation, characterized by local increase of $\mathrm{Mn}$ and $\mathrm{Fe}\left(\mathrm{Mn}^{*}>0, D<\right.$ 0.60 ); the cause is probably a decrease of the sedimentation rate, inducing local oxidations of transition elements.

The Maestrichtian variegated claystones of the Plantagenet Formation show the lack of organic matter, destroyed by the development of deep water exchanges, itself probably allowed by the ocean widening (Grow and Sheridan, 1981; Sheridan, Gradstein, et al., this volume). Nevertheless, the newly formed oxidizing conditions are not strong enough to determine the massive precipitation of manganese oxides (Fig. 4), which differs from other DSDP sites in the western North Atlantic at the same period (i.e., Site 105, Leg 11, Hollister et al., 1972, and Site 387, Leg 43, Tucholke et al., 1979; unpublished data). The important supply of kaolinite and illite in the clay fraction is reflected by high values of $\mathrm{Al}_{2} \mathrm{O}_{3}$ (up to $21 \%$ ), $\mathrm{Fe}_{2} \mathrm{O}_{3}$, and $\mathrm{K}_{2} \mathrm{O}$, expressed by several ratios: $\mathrm{SiO}_{2} / \mathrm{Al}_{2} \mathrm{O}_{3}, \mathrm{Al}_{2} \mathrm{O}_{3} / \mathrm{K}_{2} \mathrm{O}, \mathrm{Na}_{2} \mathrm{O} / \mathrm{K}_{2} \mathrm{O}$ (Fig. 4). $\mathrm{Mg}$ amounts are low (i.e., $\mathrm{MgO} / \mathrm{Al}_{2} \mathrm{O}_{3}$ ), in spite of the occurrence of fibrous clays in small quantity. The abundance of aluminum correlates to high values of $\mathrm{Li}$ and $\mathrm{Ti}$, which also characterizes the Upper Cretaceous at Sites 105 and 387. The low content of Mn suggests that $\mathrm{Li}$ and $\mathrm{Ti}$ do not result from the precipitation of lithiophorite after alteration of birnessite (Taylor et al., 1964; Dixon and Weed, 1977), but instead directly mark the terrigenous kaolinite, as Ni probably does.

\section{Bermuda Rise and Blake Ridge Formations}

The Cenozoic series of Hole 534A are marked by increased amounts of $\mathrm{SiO}_{2}$, whose origin differs according to the period. During the Eocene $\left(83 \% \mathrm{SiO}_{2}\right.$ in Sample 534A-20-1, $99 \mathrm{~cm}$ ), Si corresponds to the diagenetic development of opal CT. During the Miocene, $\mathrm{Si}$ rather expresses the highly detrital character of the deposit, marked by fast sedimentation rates and abundant reworked materials (Sheridan, Gradstein, et al., this volume).

The Miocene environment (Great Abaco Member of the Blake Ridge Formation) is characterized by a reducing backround $\left(\mathrm{Mn}^{*}<0\right)$, homogeneous, fairly calcareous $\left(30 \% \mathrm{CaCO}_{3}\right)$, enriched in $\mathrm{P}, \mathrm{C}_{\text {org }}$ (i.e., Sample 534A-12-1, $100 \mathrm{~cm}, 534 \mathrm{~A}-4-2,100 \mathrm{~cm}$ ), poor in $\mathrm{Mn}$ and $\mathrm{Co}$, more magnesian and sodic than potassic, which corresponds to the noticeable amounts of fibrous clays (palygorskite, sepiolite). This background is periodically interrupted by allochthonous calcareous intercalations, more oxidizing $\left(\mathrm{Mn}^{*}>0\right)$, rich in $\mathrm{CaCO}_{3}(95 \%$ in Sample 534A-7-4, $100 \mathrm{~cm}$ ), and corresponding to the maxima of smectites, which could indicate a joined reworking of calcareous and clayey upstream materials. The Sr content of biogenic particles increases upward, synchronously with the increased carbonate preservation. The dissolution of carbonates, increasing with increased depth during the Miocene, probably occurred close to the carbonate compensation depth, according to the fairly high values of the $\mathrm{Sr} / \mathrm{CaO}$ ratio (Maillot and Robert, 1980).

\section{CONCLUSION}

The drilling of Hole 534A in the Blake-Bahama Basin led to a remarkable record of Mesozoic and Cenozoic sedimentary series, deposited above Callovian oceanic basalt. The materials recovered permitted a more precise analysis and development of the lithostratigraphy than had previously been established (Sheridan et al., 1982). Shore-lab studies allowed the determination of a clay mineralogical and geochemical stratigraphy, which is tentatively interpreted in terms of paleoenvironmental evolution.

Oceanic basalts, the geochemistry of which differs according to the volcanic flow considered, are slightly in situ altered in clay minerals, systematically represented by highly crystallized smectites like tufts and boards. The contact between basalt and sediments shows the hydrothermal formation of corrensite, which corresponds to a very local metamorphism, affecting only a few centimeters thickness of sediments above the basalt. Siliceous limestones interbedded in basalt flows do not depend significantly on volcanic or terrigenous influence.

The Callovian to Barremian sediments, corresponding to the unnamed, Cat Gap, and Blake-Bahama formations, yield different kinds of information about the paleoenvironment. Whereas clay assemblages, from 10 $\mathrm{cm}$ above the last basalt flow upward, primarily reflect the continental paleoenvironment, chemical elements such as $\mathrm{Fe}$ and Mn chiefly express the influence of an increasing distance from oceanic volcanic activity. Both methods are, therefore, of a complementary significance. Because at Site 534 clay diagenetic modifications linked to the depth of burial or to particular lithologic facies seem to be of very little importance, the clay minerals are good reflections of the following land conditions: hot average climate with contrasts in seasonal humidity; tectonic relaxation periodically interrupted by the reactivation of the margins following the main seafloor 
spreading stages (Callovian-early Oxfordian, middlelate Oxfordian, Tithonian-early Berriasian, late Berriasian); immature continental morphology; and development of carbonate platforms that interfered with the supply of upstream detrital materials. The marine environment is dominated by successive oxidizing and reducing conditions for this time interval. The proximal influence of the spreading center dominates until the Tithonian; its distal influence dominates until the Berriasian/Valanginian boundary. From the Valanginian upward, the chemical sedimentation is dominated by terrigenous influences, as in most parts of the Atlantic Ocean. The calcareous turbidites intercalated in reduced sediments are primarily derived from more oxidized areas, located on the continental side of the Blake-Bahama Basin.

The Aptian to Maestrichtian sediments, including the Hatteras and Plantagenet formations, correspond to fairly more reducing conditions, with the carbonate compensation depth above the site depth of deposition. Tectonic rejuvenations occurred, as expressed by the clay mineral stratigraphy, especially during the Maestrichtian, when deep oceanic circulations developed after the definitive separation of American and European-African continental domains and the opening of the southern Labrador Sea. The long-distance transport of fine detrital particles was extended on land and in the ocean, and this transport affected minerals formed in pedogenic and sedimentogenic conditions as different as kaolinite (marked by $\mathrm{Ti}$ and $\mathrm{Li}$ ), smectites, and fibrous clays.

Chiefly represented by Miocene sediments (Great Abaco Member of the Blake Ridge Formation), but also by Eocene zeolitic clays (Bermuda Rise Formation) and Pleistocene mud (Site 391, located close to Site 534), the Cenozoic sediments correspond again to more reduced conditions, with periodical intercalations of allochthonous and oxidized carbonates, and to a location close to the CCD. The clay stratigraphy expresses the world cooling and humidification initiated after the Eocene, and developed step by step until the Pleistocene, as well as the massive development of Miocene perimarine basins where fibrous clays were formed and periodically reworked toward the open ocean.

\section{ACKNOWLEDGMENTS}

We are greatly indebted to CNEXO (France) for financial support (Grant No. 80/6 231). We gratefully acknowledge the U.S. National Science Foundation, the shipboard party of DSDP Leg 76, and especially M. Moullade, who was responsible for additional sampling. M. Bocquet, J. Carpentier, M. Deremaux, F. Dujardin, and P. Recourt provided technical assistance. The manuscript was improved by the accurate and useful reviews of M. Moullade and R. E. Sheridan.

\section{REFERENCES}

Benson, W. E., Sheridan, R. E., et al., 1978. Init. Repts. DSDP, 44: Washington (U.S. Govt. Printing Office).

Berggren, W. H., and Hollister, C. D, 1977. Plate tectonics and paleocirculation. Commotion in the Ocean. Tectonophysics, 38:11-48.

Beutelspacher, H., and Van der Marel, H. W., 1968. Atlas of Electron Microscopy of Clay Minerals and Their Admixtures: Amsterdam (Elsevier).

Chamley, H., 1971. Recherches sur le sedimentation argileuse en Méditerraneé. Sci. Geol. Mem., Strasburg (France), 35:1-215. 1979. North Atlantic clay sedimentation and paleoenvironment since the late Jurassic. In Talwani, M., Hay, W., Ryan, W. B.
F. (Eds.), Deep Drilling Research in the Atlantic Ocean: Continental Margins and Paleoenvironment. Am. Geophys. Union, Maurice Ewing Ser., 3:342-361.

1981. Long-term trends in clay deposition in the ocean. Oceanol. Acta, 26th Int. Congr. Geol., 4:105-110.

Chamley, H., and Bonnot-Courtois, C., 1981. Argiles authigènes et terrigènes de l'Atlantique et du Pacifique NW (Legs 11 et 58 DSDP): apport des terres rares. Oceanol. Acta, 4(2):229-238.

Chamley, H., Debrabant, P., Foulon, J., and Leroy, P., 1980. Contribution de la minéralogie et de la géochimie à l'histoire des marges nord-atlantiques depuis le Jurassique supérieur (Sites 105 et 367, DSDP). Bull. Soc. Geol Fr. Ser. 7, 22:745-755.

Chamley, H., and Robert, C., 1979. Late Cretaceous to early Paleogene environmental evolution expressed by the Atlantic clay sedimentation. In Christensen, W. K., and Birkelung, T. (Eds.), Proc. Cretaceous-Tertiary Boundary Events Symp. Copenhagen, 2:71-77.

, in press. Paleoenvironmental significance of clay deposits in Atlantic Black Shales. Cretaceous Res.

Debrabant, P., and Chamley, H., 1982. Influences océaniques et continentales dans les premiers dépôts de l'Atlantique Nord. Bull. Soc. Geol. Fr. Seance Spec. Lille, Dec. 1981, Ser. 7, 24:473-486.

Debrabant, P., and Foulon, J., 1979. Expression géochimique des variations du paléoenvironment depuis le Jurassique supérieur sur les marges nord-atlantiques. Oceanol. Acta, 2:469-476.

Decommer, H., and Chamley, H., 1981. Environnements mésozoïques du Nord de la France, d'après les données des árgiles et du palynoplancton. C. R. Acad. Sci. Paris II, 293:695-698.

Dixon, J. B., Weed, S. B., 1977. Minerals in Soil Environments. Soil Sci. Soc. Am. Proc., 948.

Frakes, L. A., 1979. Climates Throughout Geologic Times: Amsterdam (Elsevier).

Giblin, P., 1979. Mineralogie et geochimie de la limite Cretace-Tertiaire dans quelques forages oceaniques profonds. These 3 eme cycle, Strasbourg, France.

Grow, J. A., and Sheridan, R. E., 1981. Structure and evolution of the U.S. Atlantic continental margin. Oceanol. Acta, 26th Int. Congr. Geol., 4:11-20.

Hollister, C. D. Ewing, J. I., et al., 1972. Init. Repts. DSDP, 11: Washington (U.S. Govt. Printing Office).

Humphris, S. E., and Thompson, G., 1978. Hydrothermal alteration of oceanic basalts by seawater. Geochim. Cosmochim. Acta, 42: $107-125$.

Juteau, T., Noack, Y., Whitechurch, H., and Courtois, C., 1980. Mineralogy and geochemistry of alteration products in Holes 417A and 417D basement samples (Deep Sea Drilling Project Leg 51). In Donnelly, T., Francheteau, J., Bryan, W., Robinson, P., Flower, M., Salisbury, M., et al., Init. Repts. DSDP, 51, 52, 53, Pt. 2: Washington (U.S. Govt. Printing Office), 1273-1298.

Kristmanndottir, H., 1976. Types of clay minerals in hydrothermally altered basaltic rocks, Reykjanes, Iceland. Jokull, 26:30-39.

Laputina, I. P., Muravitskaja, G. N., Zvjagin, B. B., and Gradusov, B. P., 1980. Clay minerals in basalts from Deep Sea Drilling Project Sites 417 and 418. In Donnelly, T., Francheteau, J., Bryan, W., Robinson, P., Flower, M., Salisbury, M., et al., Init. Repts. DSDP , 51, 52, 53, Pt. 2: Washington (U.S. Govt. Printing Office), $1265-1272$.

Maillot, H., and Robert, C., 1980. Minéralogie et géochimie des sédiments crétacés et cénozoïques dans l'Océan Atlantique Sud (marge africaine, dorsale médio-atlantique). Bull. Soc. Geol. Fr., 22: 779-789.

Melson, W. G., and Thompson, G., 1973. Glassy abyssal basalts, Atlantic seafloor near St Paul's rocks: petrography and composition of secondary clay minerals. Geol. Soc. Am. Bull., 84:703-716.

Millot, G., 1964. Géologie des Argiles. Paris (Masson).

Paquet, H., 1969. Evolution géochimique des minéraux argileux dans les altérations et les sols des climats méditerranéens et tropicaux à saisons contrastées. Sci. Geol. Mem., 30:1-210.

Pastouret, L., Auffret, G. A., and Chamley, H., 1978. Microfacies of some sediments from the Western North Atlantic: paleoceanographic implications (Leg 44 DSDP). In Benson, W. E., Sheridan, R. E., et al., Init. Repts. DSDP, 44: Washington (U.S. Govt. Printing Office), 477-501.

Rangin, C., Desprairies, A., Fontes, J.-C., Jehanno, C., and Vernhet, S., in press. Metamorphic processes on sediments at contact 
with young oceanic crust. East Pacific Rise, Leg 65. In Lewis, B., Robinson, P., et al., Init. Repts. DSDP, 65: Washington (U.S. Govt. Printing Office).

Reyre, Y., 1980. Peut-on estimer l'évolution des climats jurassiques et crétacés d'après la palynologie? Mem. Mus. Nat. Hist. Nat. Ser. $B, 27: 247-260$.

Scheidegger, K. F., and Stakes, D. S., 1980. X-Ray diffraction and chemical study of secondary minerals from Deep Sea Drilling Project, Leg 51, Holes 417A and 417D. In Donnelly, T., Francheteau, J., Bryan, W., Robinson, P., Flower, M., Salisbury, M., et al., Init. Repts. DSDP, 51, 52, 53, Pt. 2: Washington (U.S. Govt. Printing Office), 1253-1264.

Sheridan, R. E., Gradstein, F. M., and Shipboard Scientific Party, 1982. Early history of the Atlantic Ocean and gas-hydrates on the
Blake Outer Ridge. Results of the Deep Sea Drilling Project Leg 76. Geol. Soc. Am. Bull., 93(9):876-885.

Taylor, R. M., McKenzie, R. M., and Norrish, K., 1964. The mineralogy and chemistry of manganese in some Australian soils. Aust. J. Soil Res., 2:235-248.

Tucholke, B. E., Vogt, P. R., et al., 1979. Init. Repts. DSDP, 43: Washington (U.S. Govt. Printing Office).

Weaver, C. E., and Beck, K. C., 1977. Miocene of the southeastern United States: a model for chemical sedimentation in a peri-marine environment. Sediment. Geol., 17(1/2):1-234.

Date of Initial Receipt: March 10, 1982 

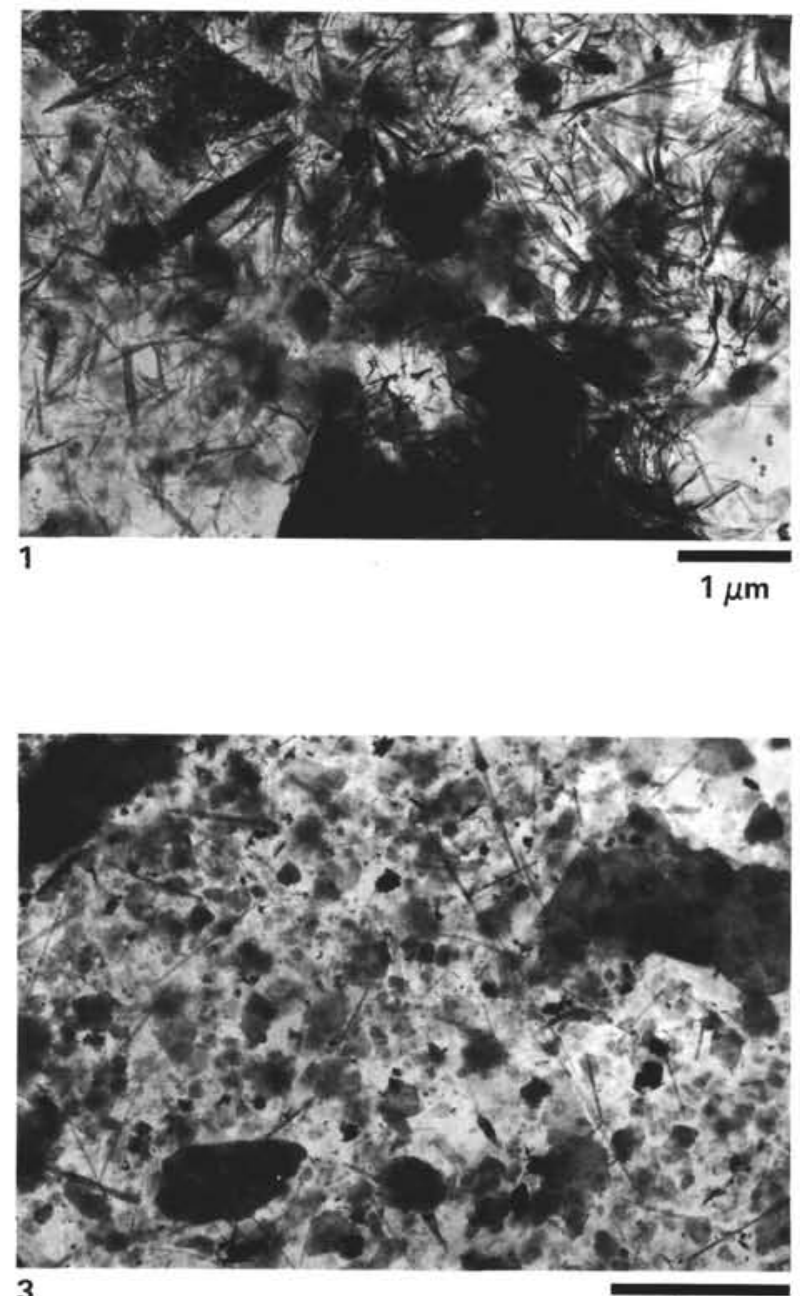

$1 \mu \mathrm{m}$

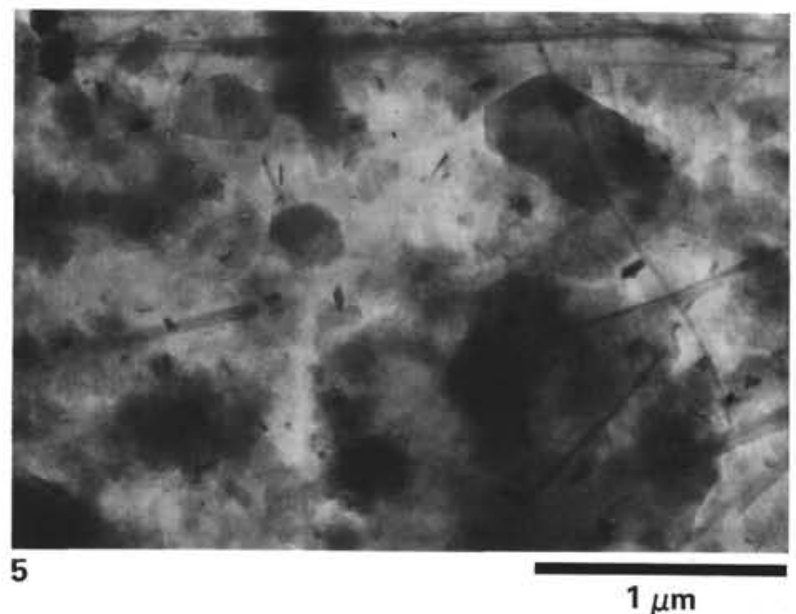

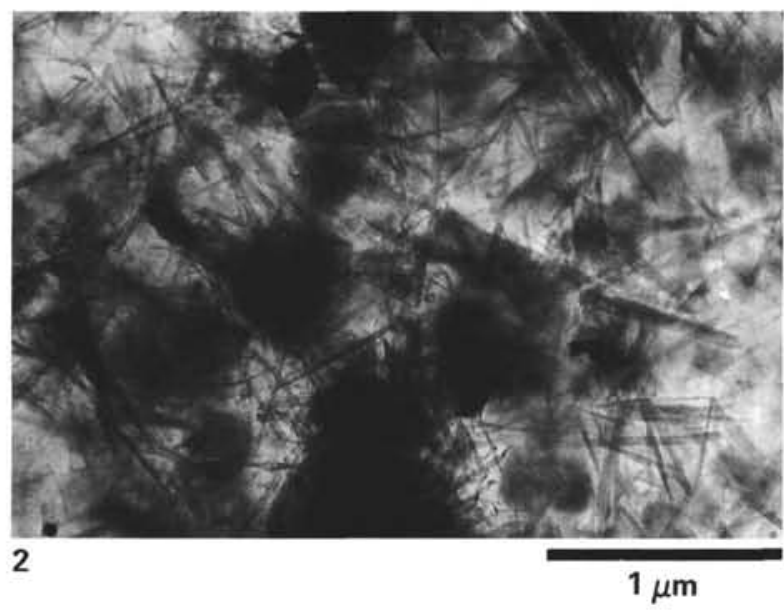
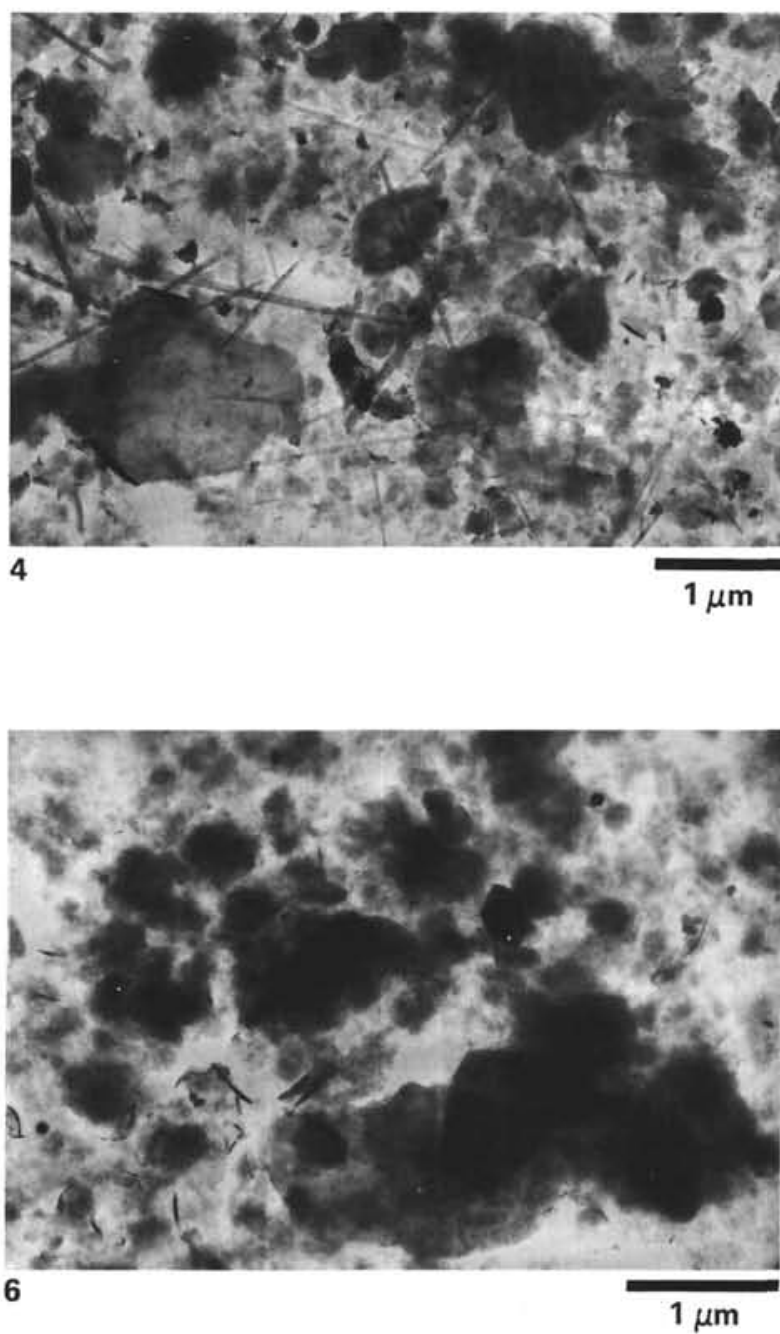

Plate 1. 1-2. Sample 534A-4-2, $100 \mathrm{~cm}$. Early Miocene, Great Abaco Member, Blake Ridge Formation. (Sepiolite short and often bundled fibers, blurred smectites, few illite and kaolinite sheets, radiolarian debris.) 3-5. Sample 534A-24-1, $32 \mathrm{~cm}$. Early Maestrichtian, Plantagenet Formation. (Abundant kaolinite hexagons and well-shaped illite sheets, smectite with blurred contours, scarce short to long fibers of palygorskite and sepiolite.) 6. Sample 534A-35-2, $120 \mathrm{~cm}$. Middle Albian, Hatteras Formation. (Abundant illite and smectite, kaolinite hexagonal sheets.) 

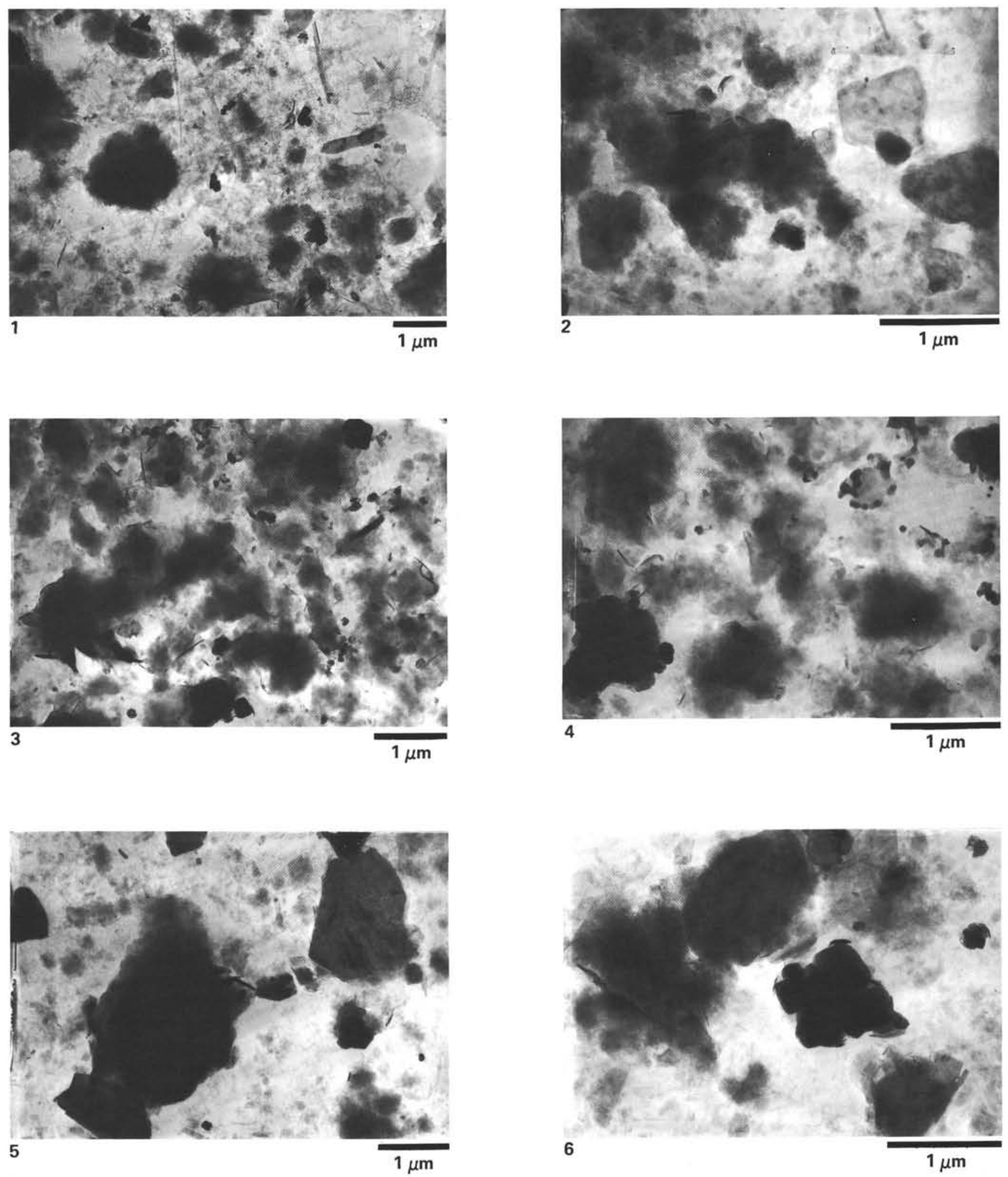

Plate 2. 1. Sample 534A-76-3, $48 \mathrm{~cm}$. Early Valanginian, Blake-Bahama Formation. (Abundant smectite blurred particles, presence of noticeable amounts of broken and short fibers of palygorskite.) 2. Sample 534A-91-1, $101 \mathrm{~cm}$. Early Berriasian, Blake-Bahama Formation. (Smectite abundant, illite in noticeable amounts, few fibers.) 3-4. Sample 534A-119-1, $113 \mathrm{~cm}$. Callovian-Oxfordian, "unnamed" formation. (Abundant smectite sheets with blurred contours, few illite particles.) 5-6. Sample 534A-127-1, $51 \mathrm{~cm}$. Callovian, "unnamed" formation. (Wellshaped and abundant illite and chlorite, small particles of irregular mixed layers and smectite with blurred contours, few kaolinite hexagons, very few fibers.) 

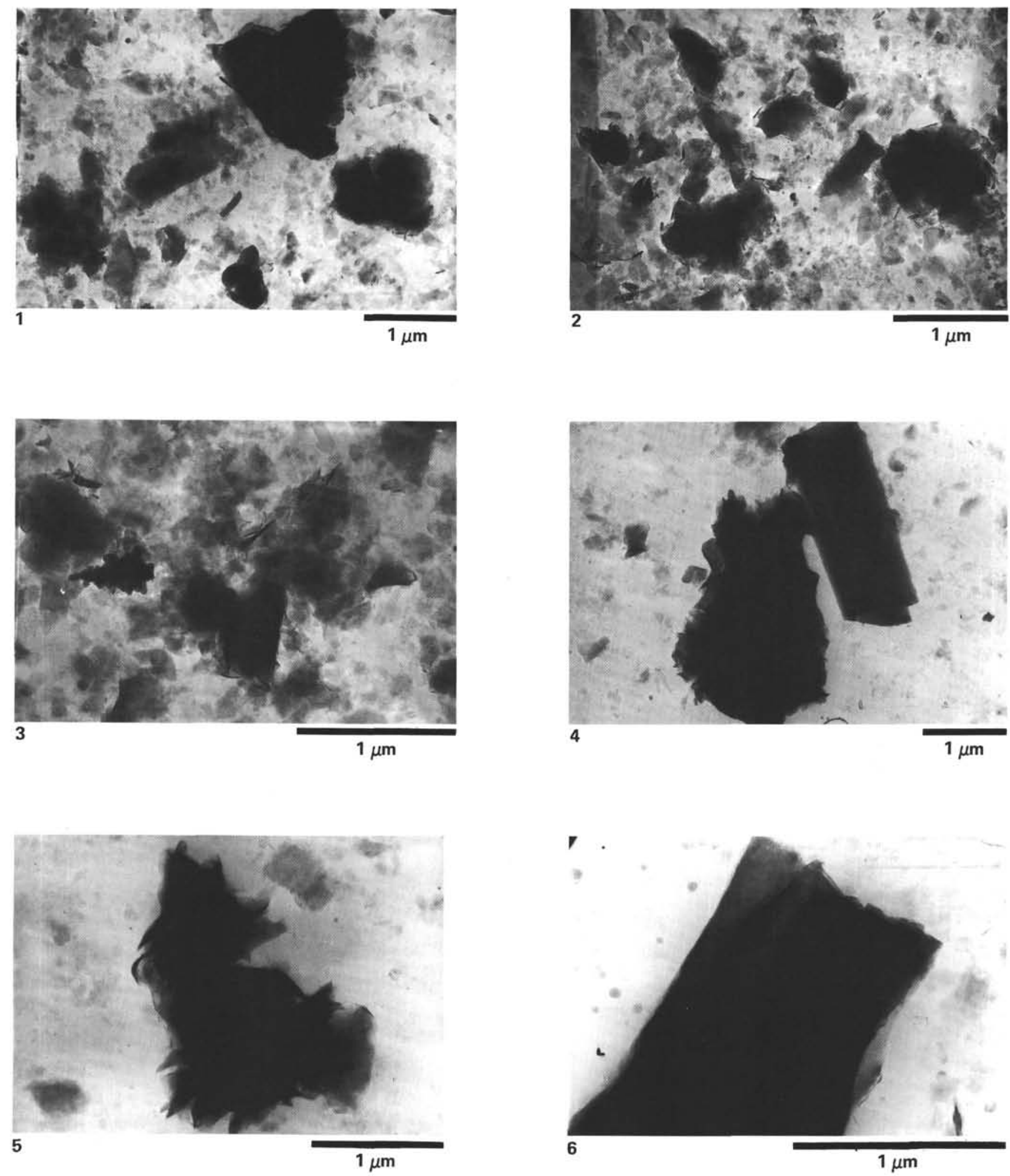

Plate 3. 1-3. Sample 534A-127,CC (10 cm). Callovian. (Precise contact between basalt and sediment. Corrensite [regular chlorite-smectite mixed layer] as refringent, well-shaped, and diversely sized sheets.) 4-6. Sample 534A-128-1, $88 \mathrm{~cm}$. (Weakly altered basalt. Authigenic smectite as tufts or broad boards.) 